\title{
Small-scale distribution of microbes and biogeochemistry in the Great Barrier Reef
}

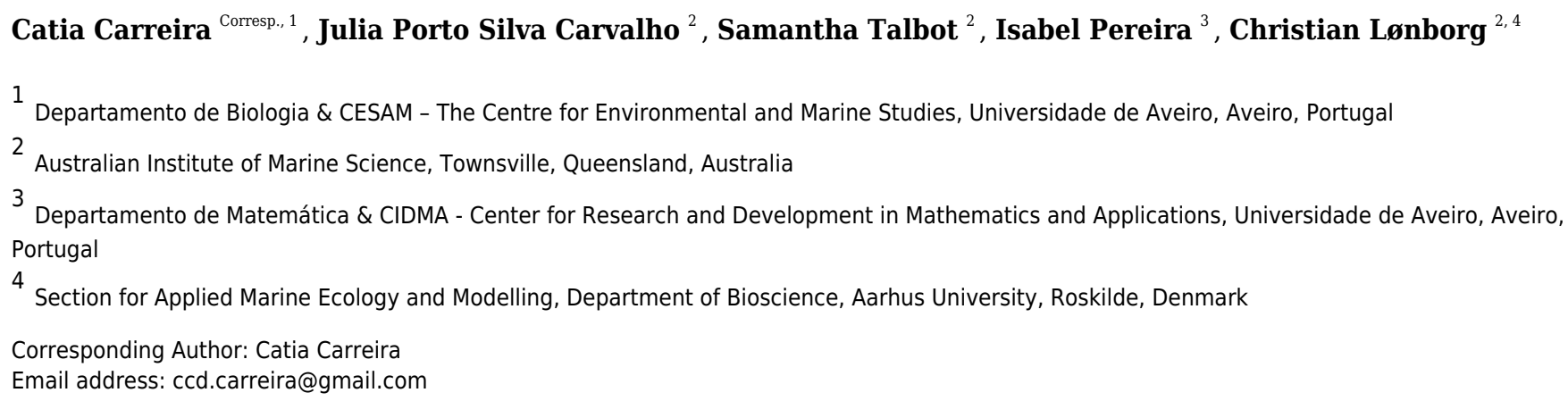

Microbial communities distribute heterogeneously at small-scales $(\mathrm{mm}-\mathrm{cm})$ due to physical, chemical and biological processes. To understand microbial processes and functions it is necessary to appreciate microbes and matter at small scales, however, few studies have determined microbial, viral, and biogeochemical distribution over space and time at these scales. In this study, the small-scale spatial and temporal distribution of microbes (bacteria and chlorophyll a), viruses, dissolved inorganic nutrients and dissolved organic carbon were determined at five locations (spatial) along the Great Barrier Reef (Australia), and over 4 consecutive days (temporal) at a coastal location. Our results show that: 1 ) the parameters show high small-scale heterogeneity; 2) none of the parameters measured explained the bacterial abundance distributions at these scales spatially or temporally; 3) chemical (ammonium, nitrate/nitrite, phosphate, dissolved organic carbon, and total dissolved nitrogen) and biological (chl $a$, and bacterial and viral abundances) measurements did not reveal significant relationships at the small scale; and 4) statistically significant differences were found between sites/days for all parameter measured but without a clear pattern. 


\section{Small-scale distribution of microbes and biogeochemistry in the Great Barrier Reef}

2

3 Cátia Carreira*1, Júlia Porto Silva Carvalho², Samantha Talbot ${ }^{2}$, Isabel Pereira ${ }^{3}$, Christian 4 Lønborg 2,4

$6{ }^{1}$ Departamento de Biologia \& CESAM - The Centre for Environmental and Marine Studies, 7 Universidade de Aveiro, Aveiro, Portugal

$8 \quad{ }^{2}$ Australian Institute of Marine Science, Townsville, Queensland, Australia

9 32Departamento de Matemática \& CIDMA - Center for Research and Development in Mathematics 10 and Applications, Universidade de Aveiro, Aveiro, Portugal

$11{ }^{4}$ Section for Applied Marine Ecology and Modelling, Department of Bioscience, Aarhus 12 University, Denmark

$14 *$ Corresponding author:

15 Cátia Carreira

16 Campus de Santiago, Aveiro, 3810-193, Portugal

17 Email address: ccd.carreira@gmail.com

\section{Abstract}

20 Microbial communities distribute heterogeneously at small-scales (mm-cm) due to physical,

21 chemical and biological processes. To understand microbial processes and functions it is

22 necessary to appreciate microbes and matter at small scales, however, few studies have

23 determined microbial, viral, and biogeochemical distribution over space and time at these scales. 
24 In this study, the small-scale spatial and temporal distribution of microbes (bacteria and

25 chlorophyll $a$ ), viruses, dissolved inorganic nutrients and dissolved organic carbon were

26 determined at five locations (spatial) along the Great Barrier Reef (Australia), and over 4

27 consecutive days (temporal) at a coastal location. Our results show that: 1) the parameters show

28 high small-scale heterogeneity; 2) none of the parameters measured explained the bacterial

29 abundance distributions at these scales spatially or temporally; 3 ) chemical (ammonium,

30 nitrate/nitrite, phosphate, dissolved organic carbon, and total dissolved nitrogen) and biological

31 (chl $a$, and bacterial and viral abundances) measurements did not reveal significant relationships

32 at the small scale; and 4) statistically significant differences were found between sites/days for

33 all parameter measured but without a clear pattern.

35 Introduction

36 Marine bacterioplankton and phytoplankton and their associated functions are the primary

37 controls of energy and material cycling in the global ocean. How they interact with the

38 environment is therefore of pivotal importance for understanding ocean food web structure and

39 biogeochemical processes (Wiens, 1989). Depending on the process to be studied, the scale of

40 spatial resolution has to be adjusted accordingly. As microbes interact at the cellular level, it is

41 essential to describe microbial community ecology at small scales ( $\mu \mathrm{m}$ to $\mathrm{cm})$ to capture the

42 microbial functions and productivity in marine environments (Azam and Malfatti, 2007;Stocker,

43 2015). There is evidence that microbes distribute heterogeneously at small scales in marine

44 environments (Azam and Long, 2001), which has been linked to biological factors (e.g., grazing,

45 lysis), and interactions between microbes and the environment (e.g., organic matter, aggregates)

46 (e.g., Seymour et al., 2006;Stocker et al., 2008). Viruses are estimated to kill between 20-40\% of 
47 the prokaryotic community every day, with major consequences for the microbial diversity and

48 carbon cycling (Suttle, 2005). However virus-bacteria relationships are not always

49 straightforward. Viral abundances are typically tightly coupled with bacterial abundances when

50 large datasets are used (Wigington et al., 2016), however when small datasets or small volumes

51 are used, bacterial and viral abundances are not coupled (Bouvy et al., 2012;Carreira et al.,

52 2013). This difference is probably a result of the time lag between infection and replication

53 which is easier to observe at smaller scales and volumes (Carreira et al., 2013). Recently it has

54 also been proposed that viral lifestyles can be inferred from viral and microbial metagenomics

55 data (Coutinho et al., 2017), specifically as an indicator of predominance of the piggyback-the-

56 winner theory. This theory asserts that during high viral and microbial abundances, viruses will

57 switch to a lysogenic cycle, which then predominates and thus explains the negative relation

58 between virus-microbes ratio and bacterial abundances (Silveira and Rohwer, 2016). It has also

59 been demonstrated that prokaryotes can move towards a chemical cue (chemotactic behaviour),

60 as a response to point sources of organic and inorganic matter (Malmcrona-Friberg et al.,

61 1990;Hütz A, 2011). This chemotactic behaviour has been suggested to increase the microbial

62 degradation of dissolved organic matter (DOM) (Fenchel, 2002), and heterogeneous

63 environments are suggested to have higher phytoplankton production than found under

64 homogeneous condition (Brentnall et al., 2003). Such findings have implications for the way we

65 frame marine biogeochemical cycling by microbes. Models have been used previously to

66 understand the interaction between microbes and organic matter at small scales (e.g., Datta et al.,

67 2015), while other studies have used controlled experiments (e.g., Brumley et al., 2019), and

68 measured microbial distribution at small scales in a natural ecosystem (e.g., Seymour et al. 
69 2005). But none of these have measured the chemical (organic and inorganic) components

70 interacting with the microbes at small scales in a natural ecosystem.

71 The Great Barrier Reef (GBR) is situated on the continental shelf and slope of Australia's

72 north-eastern coast and is the largest contiguous coral reef system in the world. The GBR has a

73 total of $\sim 3700$ reefs which are mainly located away from shore; with the open water body

74 separating the reef matrix from the mainland known as the GBR lagoon. The system is

75 characterized by stable high temperatures, oligotrophic, sunlit, and alkaline waters (Furnas et al.,

76 2011;Uthicke et al., 2014). The microbial patchiness at the $\mathrm{cm}$ scale has been studied by

77 Seymour et al. (2005) on one reef, demonstrating a 2- to 3.5-fold changes in the viral and

78 bacterial concentrations over a distance of $12 \mathrm{~cm}$ above coral colonies. This microbial

79 heterogeneity suggests that small-scale interactions could be important in understanding the

80 microbial ecology and biogeochemistry of this system. But it remains to be understood how

81 representative these single measurements are for other locations in the GBR and how this might

82 vary over temporal scales.

83 In this study we determined the spatial and temporal variability in the small-scale

84 distribution of microbes (bacteria, and chlorophyll $a$-a proxy for phytoplankton biomass), and

85 viruses, as well as biogeochemical variables (dissolved inorganic nutrients and dissolved organic

86 carbon) at five locations along the GBR, and over 4 consecutive days at a coastal location.

87 Our aim was to determine microbial interactions with biological and chemical parameters

88 using the smallest possible volume while still performing all measurements. As such, sampling at

89 the micrometre scale $(\mu \mathrm{L})$ where single cell interactions occur, was not possible. Instead, we

90 sampled $<25 \mathrm{~mL}$, a scale that is 3 orders of magnitude larger than the microscale, but still 3 
91 orders of magnitude lower than the typical volumes collected (litre), and it is the scale where it is

92 possible to 'observe' microbial communities interacting ('microbial cities') (Carreira, 2015).

93

94 Material and methods

95

96 Study sites and sampling

Samples were collected at six sites spanning from coast to the outer reef in the Great

Barrier Reef (GBR; Fig 1; Table 1). Sites 1, 2, 3, and 5 were at coral reefs, site 4 was in the

99 Coral Sea, and site 6 was at the Australian Institute of Marine Science (AIMS) harbour (Bowling

100 Green Bay; Fig 1). Site 4 (Coral Sea) was used as a reference non-coral site. Site 6 (Bowling

101 Green Bay) is located in the inner zone of the GBR, has no coral coverage and is dominated by a nearby saltmarsh and small river. All coral reef sites showed clumps of floating Trichodesmium spp. at the surface (Carreira pers. observ.) at the time of sampling. To determine the spatial variability in the small-scale distribution of microbes, viruses and biogeochemical measurements, surface water samples were collected once at sites 1 to 5 (Fig 1, Table 1; 17 to 22 December 2014). The temporal variability in the small-scale distribution was determined at site 6 with samples collected during high tide every 24 h over four consecutive days (Fig 1, Table $1 ; 12$ to 15 January 2015). Although $24 \mathrm{~h}$ is not a temporal small scale, the objective was only to understand the changes in spatial small scale over time. Furthermore, although it has been shown

110 that there can be differences in bacterial abundances on coral reefs between day and night

111 (Weber and Apprill, 2020), our daily sampling over the 4 days occurred always during daylight

112 between $2 \mathrm{pm}$ and $5.45 \mathrm{pm}$ (Table 1; sunset at $6.55 \mathrm{pm}$ ). Niskin bottle samples collected at site 6, 
113 at the same time and days as the temporal study (days 1 to 4), were used as controls for the

114 standard sampling method.

115 Samples were collected with a device built for the purpose of this study consisting of 25

116 inlets $(5 \times 5)$ (Fig 2). With the help of a lever, all samples were collected manually, at the same

117 time from $0.5 \mathrm{~m}$ below the sea surface with the sampling taking about 5 seconds. As our

118 objective was to understand small-scale heterogeneity in the coral reef system, samples from

119 sites $1,2,3$, and 5 were taken above the coral reefs, but not in the proximity of a coral as done by

120 Seymour et al. (2005). Each inlet was connected to a $25 \mathrm{~mL}$ syringe each separated by $7 \mathrm{~cm}$,

121 representing a total sampling area of $784 \mathrm{~cm}^{2}$. This distance between the syringes was calculated

122 to account for the volume necessary for all measurements $(25 \mathrm{~mL})$ without interfering with

123 neighbouring sampling volumes. In this calculation we assume that the rapid intake of water by

124 the syringes is similar in shape to a turbulent jet (Pope, 2000). The following equations were

125 used for the calculation:

126

127

128

129

$$
V=\pi \times r^{2} \times \frac{h}{3}
$$

$\operatorname{Tan} \theta=\frac{r}{h}$

130

131 we combined equations 1 and 2 to obtain the minimum distance (r) between syringes (equation 3 ,

132 Fig S1). Equation (1) calculates the volume of a cone (V), which is the water rapidly sucked up

133 ('turbulent jet') by the syringe and equation (2) takes into account its shape. This allowed to

134 calculate the distance (r) using a known angle of $11.8^{\circ}$ (equation (3); Fig S1) (Pope, 
135 2000;Cushman-Roisin, 2019). This angle is always the same independent of the fluid used

136 (Cushman-Roisin, 2019).

137 At sites 1 to 5 temperature and salinity were recorded using a conductivity-temperature-

138 depth (CTD) profiles (Seabird SBE19Plus). At site 6 salinity samples were collected and

139 analysed in the laboratory with a Portasal Model 8410A, while temperature was measured

140 manually. Salinity and temperature varied between 32.0 and 35.6 , and 28.7 and $32.0^{\circ} \mathrm{C}$,

141 respectively (Table 1). From each syringe samples were collected for dissolved inorganic

142 nutrients (ammonium - $\mathrm{NH}_{4}{ }^{+}$, nitrate/nitrite $-\mathrm{NO}_{3}{ }^{-} / \mathrm{NO}_{2}{ }^{-}$, and phosphate $-\mathrm{HPO}_{4}{ }^{2-}$ ), dissolved

143 organic carbon (DOC), total dissolved nitrogen (TDN), chlorophyll $a(\operatorname{chl} a)$, and bacterial and

144 viral counts. A precombusted $\left(450^{\circ} \mathrm{C}, 4 \mathrm{~h}\right) \mathrm{GF} / \mathrm{F}$ filter $(13 \mathrm{~mm}$ diameter $)$ was used to filter $5 \mathrm{~mL}$

145 for inorganic nutrients analysis, and $10 \mathrm{~mL}$ of seawater for DOC and TDN analysis. DOC and

146 TDN samples were fixed with $50 \mu \mathrm{L}$ of $25 \% \mathrm{H}_{2} \mathrm{PO}_{4}$ and kept at $4{ }^{\circ} \mathrm{C}$, whereas inorganic

147 nutrients were filtered and kept at $-20^{\circ} \mathrm{C}$ until analysed. The $\mathrm{GF} / \mathrm{F}$ filters used for collecting

148 inorganic nutrients, DOC, and TDN samples were snap-frozen in liquid nitrogen and kept at -20

$149{ }^{\circ} \mathrm{C}$ for chl $a$ extraction. All syringes, filter-holders and inorganic nutrient sample tubes were acid-

150 washed in $10 \% \mathrm{HCl}$ for $24 \mathrm{~h}$, and then washed three times with Milli-Q water before use.

$151 \quad$ For bacterial and viral counts, unfiltered subsamples of $1 \mathrm{~mL}$, were collected in sterile 2

$152 \mathrm{~mL}$ Eppendorf tubes and fixed with $0.5 \%$ glutaraldehyde final concentration (25\% EM-grade,

153 Merck) for $15 \mathrm{~min}$ at $4{ }^{\circ} \mathrm{C}$, after which samples were snap-frozen in liquid nitrogen and stored at

$154-80{ }^{\circ} \mathrm{C}$ until analysis by flow cytometry (FCM).

155

156 Samples analysis 

segmented flow analysis (SFA) as described in Hansen \& Koroleff (1999). As all the determined

$159 \mathrm{NH}_{4}{ }^{+}$concentrations were below the detection limit of the method $(<0.02 \mu \mathrm{mol} \mathrm{L}-1)$ the data is 160 not shown. The detection limit and precisions for the other parameters were: $0.02 \mu \mathrm{mol} \mathrm{L}-1$ for $161 \mathrm{NO}_{3}{ }^{-} / \mathrm{NO}_{2}{ }^{-}$and $0.001 \mu \mathrm{mol} \mathrm{L}{ }^{-1}$ for $\mathrm{HPO}_{4}{ }^{2-}$. Please note that the $\mathrm{HPO}_{4}{ }^{2-}$ concentrations at site 2

162 were also below the detection limit and therefore the data is not shown. DOC and TDN

163 concentrations were measured using a Shimadzu TOC-L carbon analyser coupled in series with a 164 nitric oxide chemiluminescence detector according to Lønborg et al. (2018). Three to five 165 replicate injections of $150 \mu \mathrm{L}$ were performed per sample. Concentrations were determined by 166 subtracting a Milli-Q blank and dividing by the slope of a daily standard curve of potassium

167 hydrogen phthalate and glycine. Using the deep ocean reference (Sargasso Sea deep water, 2600 m) we obtained a concentration of $45.6 \pm 1.8 \mu \mathrm{mol} \mathrm{L}^{-1}$ (average $\pm \mathrm{SD}$ ) for DOC and $22.0 \pm 1.5$

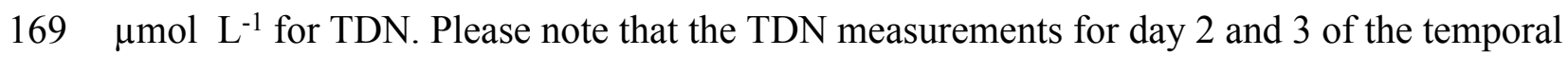
170 study are not reported due to problems with the gas supply for the nitric oxide

171 chemiluminescence detector during these specific sample runs. The detection limit for DOC and

172 TDN were $8 \mu \mathrm{mol} \mathrm{L}^{-1}$ and $0.02 \mu \mathrm{mol} \mathrm{L}^{-1}$, and the precisions were $\pm 1 \mu \mathrm{mol} \mathrm{L}^{-1}$ and $\pm 0.3 \mu \mathrm{mol}$ $173 \mathrm{~L}^{-1}$, respectively.

$174 \mathrm{Chl} a$ determinations were made by extracting the GF/F filters in ethanol (96\%) for $8 \mathrm{~h}$.

175 Samples were analysed spectrophotometrically according to Strickland \& Parsone (1972). The

176 dectection limit and precision for the chl $a$ method were $0.005 \mu \mathrm{g} \mathrm{L}^{-1}$ and $\pm 0.05 \mu \mathrm{g} \mathrm{L}^{-1}$,

177 respectively. Flow cytometric (FCM) enumeration of bacteria and viruses was carried out using a

178 standard bench top Becton-Dickinson FACSVerse FCM, equipped with an air-cooled argon laser

179 (excitation $488 \mathrm{~nm}, 15 \mathrm{~mW}$ power) according to Gasol et al. (1999) and Brussaard (2004) for 
180 bacteria and viruses, respectively. Samples were diluted (5-60 times) in TE buffer (Tris $10 \mathrm{mM}$,

181 EDTA 1 mM, pH 8.0), stained with SYBR Green I (Molecular Probes ${ }^{\circledR}$, Invitrogen Inc., Life

182 Technologies ${ }^{\mathrm{TM}}$, NY, USA) to a final concentration of $10^{-4}$ of the commercial stock solution.

183 Bacterial samples were incubated at ambient temperature, whereas viral samples were incubated

184 at $80^{\circ} \mathrm{C}$ (Brussaard, 2004), both in the dark for $10 \mathrm{~min}$. The trigger was set for green

185 fluorescence and the data was analysed using Flowing Software 2.5.1. (freeware;

186 http://flowingsoftware.btk.fi). The event rate was 300 bacteria s$^{-1}$ and between 300-800 viruses s-

$1871^{1}$ to avoid coincidence (Gasol et al., 1999;Brussaard, 2004). We would like to note that recent

188 research (e.g., (Forterre et al., 2013) has suggested that viral counts might also include gene

189 transfer agents (GTAs), membrane -derived vesicles (MVs), or even cell debris that might be

190 confused with viruses. However currently there is no method to distinguish between all these

191 particles, therefore, we assumed that the viral counts made by FCM are viruses.

192 Inorganic nutrients, DOC, TDN, and chl $a$ concentration, and bacterial and viral

193 abundances data were plotted using Surfer 9.0.

194

195 Statistical analyses

196 To measure small-scale heterogeneity within each site/day it was used the coefficient of

197 variation $(\mathrm{CV})$ calculated as the $($ Standard deviation/Mean $) \times 100$. Values closer to $0 \%$ indicate

198 a low variability, whereas values closer to $100 \%$ indicate a high variability (Sokal and Rohlf, 199 1995).

200 To understand differences in concentrations/abundance between sites/days, boxplots were

201 made using the average values for each site/day. To compare the distributions of the independent

202 samples, the non-parametric Kruskall-Wallis tests were performed for the spatial and temporal 
203 data sets because for each variable at least one subgroup (for site or day) failed the normality

204 condition for parametric tests (Agresti, 2007). Multiple comparison tests were also performed to

205 understand which pairs of sites/days had the biggest differences. For these pairwise comparisons

206 two tests were performed: Nemenyi tests with Chi-squared approximation and the Dunn's tests for

207 multiple comparisons with the Bonferroni adjustment method (Dun, 1964).

208 To identify which variables were more linearly correlated, and determine the 209 correspondent magnitude, Pearson correlation coefficients were calculated, considering each

210 site/day and all sites/days combined. Additionally, due to the fact in most cases the data normality

211 was violated, we calculated Spearman correlation $\left(\mathrm{R}_{\mathrm{s}}\right)$ to measure the strength of a monotonic

212 relationship between paired data.

213 To understand the relation between the parameters, independent of the site and day, factor

214 analysis was applied to the data. A factor analysis is used to describe an eventual correlation

215 between several observed variables in regard to another group of non-observed variables, of

216 smaller dimension, named factors (Johnson and Wichern, 2007). To perform the factor analysis all

217 variables were considered, regardless of site, as there were no significant correlations between the

218 variables, according to Bartlett's test of sphericity ( $\mathrm{p}$ value $<0.001$ ). In order to classify the

219 variables, cluster analyses were performed in the spatial and temporal data. For the temporal data,

220 cluster analysis was tested, but without meaningful results. R (1.1.442) and SPSS (v25) software

221 were used for the statistical analyses.

Results

\section{Small scale variability for each site and day}



spatial and temporal studies, there was a high small-scale heterogeneity (up to $76 \%$ for chl $a$ ) for chl $a, \mathrm{NO}_{3}{ }^{-} / \mathrm{NO}_{2}{ }^{-}$and $\mathrm{HPO}_{4}{ }^{2-}$ and lower heterogeneity for DOC, and bacterial and viral abundances. With the exception of $\operatorname{chl} a$, the chemical variables were more variable, than the biological within each site and day (Table 2 and 3). Next is given a description of the small-scale variability for each parameters for the sites and days measured. site 1 had the highest (37\%; Table 2, Fig. 3). In the temporal study, the highest variability was observed at day 1 (45\%) and lowest at day 3 (10\%) (Table 3, Fig 4). Maximum differences observed between two nearby points in the spatial and temporal studies were of $2.6 \mathrm{x}$ and $3.6 \mathrm{x}$, respectively (Fig 3 and 4). Also site 1 showed the highest heterogeneity in $\mathrm{HPO}_{4}{ }^{2-}$ concentrations (27\%), and sites 4 and 5 the lowest (20\%; Table 2, Fig 3$)$. In the temporal study the heterogeneity was highest at day 4 (26\%), and lowest at day 3 (10\%; Table 3, Fig 4). The maximum variability between nearby points was of $2.4 \mathrm{x}$, both spatially and temporally. DOC concentrations showed the highest heterogeneity at sites 2 and 3 (13\%; Table 2, Fig 3), while the lowest was found at site 5 (6\%). DOC showed the lowest heterogeneity of all measured 242 parameters at all sites. The DOC concentrations in the temporal study were higher than in the 243 spatial study, but the heterogeneity was lower. The highest heterogeneity was of $5 \%$ at day 3 , 244 and the lowest just $4 \%$ all other days (Table 3, Fig 4). A maximum variability of $1.5 \mathrm{x}$ and $1.2 \mathrm{x}$ 245 between two nearby point was found spatially and temporally. Finally, TDN varied most at site 3 $246(24 \%)$ and least at site 4 (9\%; Table 2, Fig 3). A maximum variability of $3 \times$ was found between 247 points. In the temporal study, TDN was only measured on days 1 and 4, and the heterogeneity 248 was low in those two days measured (9 and $6 \%)$. 
250 site $5(68 \%)$ and the lowest at site 2 (43\%; Table 2, Fig 5). In the temporal study the

251 heterogeneity was higher than found in the spatial study, with a maximum at day 3 (76\%).

252 Differences between nearby points were $7.9 \mathrm{x}$ and $25.5 \mathrm{x}$, spatially and temporally.

Bacterial and viral abundances showed generally similar and low heterogeneity both

254

255

256

257

258

259

260

261

262

263

264

265

266

267

268

269

270

271

spatially and temporally, with viral abundances being nearly 1 order of magnitude higher than bacteria. Bacterial abundances showed similarly low heterogeneity at site 2 and day 1 (4\% and 5 $\%$ ), and high at site 3 and day 3 (15\% and 19\%; Table 2 and 3, Fig 5 and 6). Viral abundances showed lowest heterogeneity at sites 1 and day $1(6 \%$ and $9 \%)$, while highest heterogeneity was found at sites 2 and 3, and day $2(15 \%$ and $13 \%$; Table 2 and 3, Fig 5 and 6). Finally, the VBR showed low heterogeneity at sites 4 and $5(9 \%)$ and day $1(10 \%)$, and highest heterogeneity was observed at site $3(15 \%)$ and day 3 (20\%; Table 2 and 3, Fig 5 and 6). It should be noted that the values measured (except for nitrogen) were one order of magnitude higher than its precision, and the difference between measured values was mostly higher than the precision, thereby allowing to detect real variability between samples.

Overall, although no clear pattern emerged, site 3 (furthest north) and day 3 (high nutrient concentrations) had most parameters with highest heterogeneity, while site 5 (furthest south) and day 1 (low nutrient concentrations) had most parameters with the lowest heterogeneity.

\section{Comparing small-scale variability between sites and days}

All sites showed comparable concentrations/abundances overall, with the exception of bacterial and viral abundances at the non-coral site 4 (Coral Sea) that were on average $1.8 \mathrm{x}$ and $2.6 \mathrm{x}$ lower compared to the other sites (Table 2, Fig 5). Over the four days, nutrient 
272 concentrations increased while bacterial and viral abundances decreased, and chl $a$ and VBR

273 showed no differences (Table 3, Fig 6, Fig S2). The inorganic nutrients $\left(\mathrm{NO}_{3}{ }^{-} / \mathrm{NO}_{2}{ }^{-}\right.$and $\left.\mathrm{HPO}_{4}{ }^{2-}\right)$

274 showed comparable average concentrations between the outer reef and Coral Sea sites (Table 2,

275 Fig 3), and to site 6 (temporal study; Table 3; Fig 4), except for day 4 when concentrations

276 increased by $11.0 \mathrm{x}$ and $1.4 \mathrm{x}$ compared to day 1 (lowest concentrations, but still comparable to

277 the sites). DOC was slightly higher at site 6 (average range over the 4 days: $100 \pm 4 \mu \mathrm{mol} \mathrm{L}^{-1}$ to

$278118 \pm 6 \mu \mathrm{mol} \mathrm{L}^{-1}$; Table 3, Fig 4), compared to the coral sites (average range over sites 1, 2, 3,

279 and 5: $83 \pm 11 \mu \mathrm{mol} \mathrm{L}^{-1}$ to $\left.90 \pm 9 \mu \mathrm{mol} \mathrm{L}^{-1}\right)$ and Coral Sea site $\left(89 \pm 8 \mu \mathrm{mol} \mathrm{L}^{-1}\right.$; Table 2, Fig 3).

280 TDN showed slightly higher concentrations at site 6 (particularly day 4) compared to the other

281 sites (Table 2 and 3, Fig 3 and 5). Chl $a$ was on average lower at site 6 compared to all other sites

282 (Table 2 and 3, Fig 5 and 6). Bacterial and viral abundances were on average higher at site 6

283 (total average of the 4 days: $18.1 \pm 3.1 \times 10^{5} \mathrm{~mL}^{-1}$ and $104.8 \pm 17.3 \times 10^{5} \mathrm{~mL}^{-1}$, respectively;

284 Table 3, Fig 6), compared to the coral sites (average range: $7.8 \pm 0.5 \times 10^{5} \mathrm{~mL}^{-1}$ to $12.5 \pm 1.9 \mathrm{x}$

$28510^{5} \mathrm{~mL}^{-1}$; and $41.3 \pm 2.7 \times 10^{5} \mathrm{~mL}^{-1}$ to $58.2 \pm 8.8 \times 10^{5} \mathrm{~mL}^{-1}$ respectively; Table 2, Fig 5).

286 Overall site 6 (temporal study) showed either similar or slighly higher

287 concentrations/abundances when compared to the other sites (coral sites and non-coral - Coral

288 Sea), but these results should be taken with cautions as there was no temporal follow-up at sites 1 289 to 5.

290 Comparing the concentrations and abundances obtained with a Niskin bottles during the

291 temporal study (Table S5) with the range of values for each parameter over the 4 days (Table 3),

292 the values are generally within these ranges, hence also showing the increase in nutrients and

293 decrease in bacterial and viral abundances over the 4 days. 
295 abundances) pairwaise comparisons between sites and days were performed. The Kolmogorov-

Smirnov tests showed that the spatial and temporal data were not normally distributed for each variable. Concerning each variable in the study, the Kruskall-Wallis test revealed that at least one of the samples for each site/day is significantly different from the others. However, the pairwise comparisons using suitable non-parametric tests for multiple comparisons (Nemenyi-tests with Chi-squared approximation and Dunn's tests) showed statistically significant differences between some sites and days for each variable, but these were 'random' and without a clear link between sites/days. The p values are shown in the supplement material (Table S5 and S6).

Overall, statistically significant differences were found, but there were no clear patterns spatially or temporally as determined by non-parametric tests, i.e., no site and day or combinations of sites and days showed a trend or similar behaviour for all the parameters or a subsection of these (Fig 7 and 8). DOC showed the least statistical differences between sites (Fig 7, Table S5), while chl $a$ showed the least differences between days (Fig 8, Table S6).

Pearson and Spearman correlations were determined between all parameters within a site/day and between sites/days without any clear results (Table S1, S2, S3, and S4). Most correlations did not exhibit a strong linear relationship or even a monotonic relationship between the variables in study (Table S1, S2, S3, and S4). However it can be highlighted that spatially, bacterial abundances correlated negatively with $\mathrm{HPO}_{4}{ }^{2-}$ and positively with viruses $\left(\mathrm{n}=25, \mathrm{R}^{2}=\right.$ -0.54 and 0.55 , respectively), and temporally bacterial abundances correlated negatively with $\mathrm{NO}_{3}{ }^{-} / \mathrm{NO}_{2}{ }^{-}$and $\mathrm{HPO}_{4}{ }^{2-}\left(\mathrm{n}=25, \mathrm{R}^{2}=-0.75\right.$ and -0.50$)$. The correlation between all bacterial and all viral abundances (spatial and temporal) showed a positive correlation $\left(n=325, R^{2}=0.75\right.$; Fig 
316 9). This correlation showed an intercept not significantly different from zero, indicating a tight

317 link between bacterial and viral abundances.

318 Although no relations were found between the parameters at the different sites and days,

319 factor analysis was applied to understand the relation between the parameters. The factor

320 analysis showed that the variables can be decomposed into two factors, the chemical $\left(\mathrm{NO}_{3}{ }^{-} / \mathrm{NO}_{2}{ }^{-}\right.$

321 and DOC) and biological (chl $a$ and bacterial and viral abundances) groups (Fig. S3). It should

322 be noted that $\mathrm{HPO}_{4}{ }^{2-}$ and TDN were excluded from this analysis because the correspondent anti-

323 image matrices values were smaller than 0.5 ( 0.340 and 0.372 , respectively) meaning that we

324 discarded these variables since its partial correlation values are considered too small to apply

325 factorial analysis. Overall these results show: 1$)$ that the chemical variables $\left(\mathrm{NO}_{3}{ }^{-} / \mathrm{NO}_{2}{ }^{-}\right.$and

326 DOC) are more related to each others than to the biological variables (chl $a$ and bacterial and

327 viral abundances), and likewise for the biological variables, 2) the chemical variables do not

328 explain the bacterial abundances, and 3) given the biological variables are more related to each

329 others, there is a higher likelihood they could explain the bacterial abundaces, but the results are

330 insufficient to make a firm conclusion. Cluster analysis showed (Fig. S4A) a clear grouping

331 between the biological (chl $a$, and bacterial and viral abundances) and the chemical $\left(\mathrm{NO}_{3}^{-} / \mathrm{NO}_{2}^{-}\right.$,

$332 \mathrm{HPO}_{4}{ }^{2-}$, DOC and TDN) between all sites, whereas the classification was less clear between the

333 days (Fig. S4B). Here bacterial and viral abundances grouped together, while DOC, chl $a, \mathrm{NO}_{3}^{-}$

$334 / \mathrm{NO}_{2}{ }^{-}$and $\mathrm{HPO}_{4}{ }^{2-}$ ) clustered. Please note that the TDN data was not included in this analysis as

335 there was no data for days 2 and 3.

336 The dataset generated for this study can be found at

337 https://figshare.com/articles/Figshare_Carreira_2020Feb_xlsx/11841168. 


\section{Discussion}

340 A major challenge in microbial ecology is to understand how microbial communities are

341 influenced by changing environmental conditions. To date, however, most studies have explored

342 these links using both larger volumes (litres) and spatial scales $(\mathrm{km})$, ignoring that the water

343 column is in fact heterogeneous at smaller scales (Azam and Malfatti, 2007). Previous theoretical

344 and laboratory based studies have suggested that both microbes and their growth substrates

345 (DOC, inorganic nutrients) have a variable distribution at small scale (Blackburn et al.,

346 1998;Blackburn and Fenchel, 1999), but few studies have actually determined this combined

347 heterogeneity in field studies (Seymour et al., 2006; Weber and Apprill, 2020). Our study shows

348 the first in-situ heterogeneous 2-dimensional distribution of chemical (ammonium, nitrate/nitrite,

349 phosphate, dissolved organic carbon, and total dissolved nitrogen) and biological (chl $a$, and

350 bacterial and viral abundances) variables at the $\mathrm{cm}$ scale over spatial and temporal scales.

351 Nonetheless the authors are aware that the sampled volume used in this study $(\mathrm{ml})$ does not fully

352 replicate interactions between the biogeochemistry and single microbes observed with $\mu \mathrm{L}$

353 samples, instead it more closely resembles interactions between microbial communities and bulk

354 concentrations of inorganic and organic matter (Carreira, 2015). However this study is intended

355 as a first approach to understand these interactions and more detailed studies at smaller scales are

356 therefore needed. Furthermore, we have used this large dataset with 25 replicates per site/day to

357 compare the data between sites and days.

358 At the resolution of our measurements none of the variables $\left(\mathrm{NO}_{3}^{-}-\mathrm{NO}_{2}^{-}, \mathrm{HPO}_{4}{ }^{2-}, \mathrm{DOC}\right.$,

359 TDN, chl $a$, or viruses) explained the small-scale distribution of bacterial abundances at the

360 studied sites and days (Table S1 and S2). Nonetheless site 3 (furthest north) showed more

361 parameters with higher heterogeneity, compared to site 5 (furthest south). At site 6 (Bowling 
362 Green Bay), day 3 showed more parameters with higher heterogeneity compared to day 1 . The

363 increase of nutrients in Bowling Green Bay, observed at day 3, could explain the higher

364 heterogeneity observed at this day, perhaps as a results of chemotactic behaviour by the microbes

365 in search of food (Malmcrona-Friberg et al., 1990;Hütz A, 2011).

366 The high variability of $\operatorname{chl} a$ (indicative of phytoplankton biomass) and nutrients found in

367 both the spatial and temporal studies could be caused by distinct heterogeneous

368 microenvironments created by 'Phycosphere' patches (nutrient rich areas surrounding

369 phytoplankton cells resultant from their excretion), suggested to be hotspots for bacterial growth

370 (Stocker and Seymour, 2012). However, bacterial growth was not measured in our work, and no

371 clear link between chl $a$ or nutrients and bacterial abundances was observed at the scale sampled.

372 Additionally, the low variability observed for bacterial and viral abundances, and DOC might

373 suggest that the sample sizes collected for analysis (1 and $10 \mathrm{~mL})$ is too large to determine

374 heterogeneity, but it could also be due to that most DOC is refractory and large proportions of

375 cells may be dormant (Giorgio and Scarborough, 1995;Lønborg et al., 2018). Furthermore, the

376 distribution of biological and chemical variables in the ocean are known to be impacted by

377 processes occurring at a range of scales; for example, at the centimetre scale marine snow

378 formation is important, while at kilometre scales fronts and eddies can shape the distribution of

379 both chemical and biological variables (Kiørboe, 2001;Jickells et al., 2008;Baltar and Aristegui, 380 2017).

381 The concentrations of the chemical parameters and chl $a$ were comparable to previous

382 studies in the GBR (Furnas et al., 2005;Lønborg et al., 2018). Bacterial and viral abundances

383 found in our study were within the estimates found for middle shelf reef surface waters in the

384 GBR (Alongi et al., 2015), but about 4 - 6 and 5 - 7 x higher than those determined from a 
385 coastal coral reef in the GBR (Seymour et al., 2005), respectively. The Niskin bottle samples

386 taken at site 6 (temporal study) also showed concentrations and abundances within the ranges of

387 the small-scale sampling. However, sampling using a Niskin bottle clearly misses the high small-

388 scale heterogeneity determined using the $\mathrm{cm}$ scale device from the present study. Overall, the

389 average concentrations from the temporal study were higher than in the spatial study, which was

390 expected as the temporal station was closer to shore.

391 On the whole, no pattern could be statistically detected, suggesting that the controlling

392 factors and dynamics were different between sites and days. Some variability in the spatial study

393 could be attributed to the differences in sampling time as our temporal study also showed

394 differences. However the differences observed between days (Table 3; Fig S2) are comparable to

395 the differences observed between sites (Table 2), suggesting that differences between sites

396 cannot solely be due to different sampling times. In the temporal study differences in the

397 variability became more obvious over time, with nutrient concentrations increasing, while

398 bacterial and viral abundances showed an overall decrease in abundances. A recent study by

399 Weber and Appril (2020) where microbial abundances and inorganic nutrients were followed

400 over diel cycles in close proximity to corals $(5 \mathrm{~cm})$ using $\mathrm{mL}$ samples, showed clear diel changes

401 in the abundance of some microbial populations (specifically Prochlorococcus and

402 Synechococcus). Furthermore, clear differences were also observed between days in the nutrients

403 concentrations. Previous studies have also suggested that the heterogeneous distribution of

404 microbes could be linked with chemical (e.g., substrate), physical (e.g., turbulence) and/or

405 biological (e.g., viral lysis) processes or a combination of these (Stocker et al., 2008;Durham et

406 al., 2013;Carreira et al., 2015). A likely explanation for the spatial differences could be the

407 variability in the quality and type of substrate, with one previous study showing spatial 
408 differences ( $\mathrm{km}$ scale) in the concentrations of potential microbial substrate (i.e., carbohydrates

409 and proteins) in the GBR (Lønborg et al., 2017). Another important factor to consider for both

410 the spatial and temporal variability is turbulence, which increases the heterogeneity of swimming

411 phytoplankton by 10-fold (Durham et al., 2013). Other studies have found spatial differences in

412 the composition of the microbial communities (both phytoplankton and bacteria) in the GBR,

413 which could have impacted the results in our spatial component (Revelante et al., 1982;Angly et

414 al., 2016). Grazing by microzooplankton could also have influenced the spatial and temporal

415 variability, particularly of phytoplankton, as shown by the high mortality rates (75\%) by

416 microzooplankton of phytoplankton in tropical/subtropical regions (Calbet and Landry 2004).

417 Cell lysis might also have impacted the distributions of phytoplankton and bacteria, but we

418 currently lack sufficient data to conclude if this is a cause for the variability found in this study.

419 Specifically, for the temporal study, which took place at an inshore station, the daily differences

420 in nutrient level could also have been caused by variable inputs from the nearby river and/or

421 sediment resuspension, which both have been shown to increase nutrients concentrations in

422 inshore parts of the GBR (Lambrechts et al., 2010).

423 The negative correlations found between nutrients $\left(\mathrm{NO}_{3}{ }^{-} / \mathrm{NO}_{2}{ }^{-}\right.$and $\left.\mathrm{HPO}_{4}{ }^{2-}\right)$ and bacterial

424 abundance could be explained by a discrepancy between the timescales of nutrient uptake and

425 bacterial growth, or bacterial growth could be limited by other factors than $\mathrm{N}$ and $\mathrm{P}$ (e.g., carbon, 426 iron) and they therefore did not take up these nutrients (Pinhassi et al., 2006). No correlations

427 were found between bacterial and viral abundances for individual sites or days $(n=25)$, but

428 when combining all data, a relationship was observed $\left(n=325, R^{2}=0.75\right.$; Fig. 9). A lack of

429 relationship between bacterial and viral abundances has previously been found in another study

430 in a reef system with a small sample size $(n=36)$ (Bouvy et al., 2012), suggesting that small 
431 datasets might capture mismatched communities. This effect is then averaged out when larger

432 datasets are pulled together (Wigington et al., 2016). Likewise the lack of relations between

433 bacterial abundance and organic and inorganic nutrients could result from a discrepany between

434 assimilation and observable changes. Thus, as most oceanographic studies collect larger samples

435 (e.g., litres) or areas (e.g., kilometres) the interactions between microbes and viruses at small

436 scales will not be included. Likewise, we also show that "similar" sites (reef sites) show a high

437 degree of heterogeneity between them. Our results therefore indicate that caution is necessary

438 when using one site or time point as a reference and it is important to consider the scale of

439 observation to obtain an accurate understanding of microbial interactions.

440 Overall, the spatial study showed: 1) high small-scale variability across coral and non-

441 coral sites, and 2) lower bacterial and viral abundances in the Coral Sea compared to coral sites.

442 The temporal study showed: 1) persistent high small-scale heterogeneity over time, 2) 24h is not

443 an appropriate measure of temporal change, instead, shorter time periods should be used, and 3)

444 Niskin bottle samples showed a similar variability, but missed the heterogeneity observed using

445 the device presented, and 4) variability observed across days is comparable to that across sites,

446 hence differences between sites cannot only be attributed to different sampling times.

448 Conclusions

449 In conclusion, this study shows that at the $\mathrm{cm}$ scale measured in the GBR: 1) parameters

450 show high small-scale heterogeneity, 2) none of the parameters could explain the small-scale

451 distribution of bacteria spatially or temporally; 3) at the scales measured no significant relation

452 were found, and 4) statistical differences were found for the measured parameters between sites

453 and days. As such, further studies using smaller scales than the ones used in the present study 
$454(\mathrm{~cm})$, but that include biological and chemical parameters, and rates of production/degradation 455 are needed.

456

457 Acknowledgements

458 We thank the crew of the R.V. Cape Ferguson for help at sea. The help of the Cruise leader

459 (Sven Uthicke) and participant is also acknowledged. We are thankful to Niall Jeeves for

460 building the microsampling device and Jessica Benthuysen for the calculation of the required

461 minimal distance between samples.

462

463 


\section{References}

465 Agresti, A. (2007). An Introduction to Categorical Analysis. Wiley.

466 Alongi, D.M., Patten, N.L., Mckinnon, D., Köstner, N., Bourne, D.G., and Brinkman, R. (2015).

467 Phytoplankton, bacterioplankton and virioplankton structure and function across the

468

469

470

471

472

473

474

475

476

477

478

479

480

481

482

483

484

485

486

487

488

489

490

491

492

493

494

495

496

497

498

499

500

501

502

503

504

505

506

507

508

509

510

511

512

Angly, F.E., Heath, C., Morgan, T.C., Tonin, H., Rich, V., Schaffelke, B., Bourne, D.G., and Tyson, G.W. (2016). Marine microbial communities of the Great Barrier Reef lagoon are influenced by riverine floodwaters and seasonal weather events. PeerJ 4, e1511.

Azam, F., and Long, R.A. (2001). Sea snow microcosms. Nature 414, 495-498.

Azam, F., and Malfatti, F. (2007). Microbial structuring of marine ecosystems. Nature Reviews: Microbiology 5, 782-791.

Baltar, F., and Aristegui, J. (2017). Fronts at the surface ocean can shape distinct regions of microbial activity and community assemblages down to the bathypelagic zone: the Azores front as a case study. Frontiers in Marine Science 4, 252.

Blackburn, N., and Fenchel, T. (1999). Influence of bacteria, diffusion and shear on micro-scale nutrient patches, and implications for bacterial chemotaxis. Marine Ecology Progress Series 189, 1-7.

Blackburn, N., Fenchel, T., and Mitchell, J. (1998). Microscale nutrient patches in a planktonic habitats shown by chemotactic bacteria. Science 282, 2254-2256.

Bouvy, M., Combe, M., Bettarel, Y., Dupuy, C., Rochelle-Newall, E., and Charpy, L. (2012). Uncoupled viral and bacterial distributions in coral reef waters of Tuamotu Archipelago (French Polynesia). Marine Pollution Bulletin 65, 506-515.

Brentnall, S.J., Richards, K.J., Brindley, J., and Murphy, E. (2003). Plankton patchiness and its effect on larger-scale productivity. Journal of Plankton Research 25, 121-140.

Brumley, D.R., Carrara, F., Hein, A.M., Yawata, Y., and Levin, S.A. (2019). Bacteria push the limits of chemotactic precision to navigate dynamic chemical gradients. PNAS, 1-6.

Brussaard, C.P.D. (2004). Optimization of procedures for counting viruses by flow cytometry. Applied and Environmental Microbiology 70, 1506-1513.

Carreira, C. (2015). Microscale spatial distributions of microbes in marine intertidal sediments and photosynthetic microbial mats. PhD thesis, Universiteit van Amsterdam.

Carreira, C., Larsen, M., Glud, R.N., Brussaard, C.P.D., and Middelboe, M. (2013). Heterogeneous distribution of prokaryotes and viruses at the microscale in a tidal sediment. Aquatic Microbial Ecology 69, 183-192.

Carreira, C., Piel, T., Staal, M., Stuut, J.-B.W., Middelboe, M., and Brussaard, C.P.D. (2015). Microscale spatial distributions of microbes and viruses in intertidal photosynthetic microbial mats. SpringerPlus 4.

Coutinho, F.H., Silveira, C.B., Gregoracci, G.B., Thompson, C.C., Edwards, R.A., Brussaard, C.P.D., Dutilh, B.E., and Thompson, F.L. (2017). Marine viruses discovered via metagenomics shed light on viral strategies throughout the oceans. Nat Commun 8, 15955.

Cushman-Roisin, B. (2019). Environmental Fluid Mechanics. John Wiley \& Sons, Inc. .

Datta, M.S., Sliwerska, E., Gore, J., Polz, M.F., and Cordero, O.X. (2015). Microbial interactions lead to rapid micro-scale successions on model marine particles. Nature Communications 7.

Dun, O.J. (1964). Multiple Comparisons Using Rank Sums. Technometrics 6, 241-261.

Durham, W.M., Climent, E., Barry, M., De Lillo, F., Boffetta, G., Cencini, M., and Stocker, R. (2013). Turbulence drives microscale patches of motile phytoplankton. Nature communications 4 .

Fenchel, T. (2002). Microbial behavior in a heterogenous world. Science 296, 1068-1071.

PeerJ reviewing PDF | (2020:04:47529:1:1:NEW 1 Jul 2020) 
513 Forterre, P., Soler, N., Krupovic, M., Marguet, E., and Ackermann, H.-W. (2013). Fake virus

514

515

516

517

518

519

520

521

522

523

524

525

526

527

528

529

530

531

532

533

534

535

536

537

538

539

540

541

542

543

544

545

546

547

548

549

550

551

552

553

554

555

556

557

558

559

560

561

Furnas, M., Alongi, D., Mckinnon, D., Trott, L., and Skuza, M. (2011). Regional-scale nitrogen and phosphorus budgets for the northern $\left(14^{\circ} \mathrm{S}\right)$ and central $\left(17^{\circ} \mathrm{S}\right)$ Great Barrier Reef shelf ecosystem. Continental Shelf Research 31, 1967-1990.

Furnas, M., Mitchell, A., Skuza, M., and Brodie, J. (2005). In the other 90\%: phytoplankton responses to enhanced nutrient availability in the Great Barrier Reef Lagoon. Marine Pollution Bulletin 51, 253-265.

Gasol, J.M., Zweifel, U.L., Peters, F., Fuhrman, J.A., and Hagstrom, A. (1999). Significance of size and nucleic acid content heterogeneity as measured by flow cytometry in natural planktonic bacteria. Applied and Environmental Microbiology 65, 4475-4483.

Giorgio, P.a.D., and Scarborough, G. (1995). Increase in the proportion of metabolically active bacteria along gradients of enrichment in freshwater and marine plankton: implications for estimates of bacterial growth and production rates. Journal of Plankton Research 17, 1905-1924.

Hansen, H.P., and Koroleff, F. (1999). "Automated chemical analysis," in Methods of seawater analysis, eds. K. Grasshoff, K. Kermling \& M. Ehrhardt. Wiley-VCH), 159-226.

Hütz A, S.K., Overmann J (2011). Thalassospira sp. isolated from the oligotrophic eastern Mediterranean sea exhibits chemotaxis toward inorganic phosphate during starvation. Applied Environmental Microbiology 77, 4412-4421.

Jickells, T.D., Liss, P.S., Broadgate, W., Turner, S., Kettle, A.J., Read, J., Baker, J., Cardenas, L.M., Carse, F., Hamren-Larssen, M., Spokes, L., Steinke, M., Thompson, A., Watson, A., Archer, S.D., Bellerby, R.G.J., Law, C.S., Nightingale, P.D., Liddicoat, M.I., Widdicombe, C.E., Bowie, A., Gilpin, L.C., Moncoiffé, G., Savidge, G., Preston, T., Hadziabdic, P., Frost, T., Upstill-Goddard, R., Pedrós-Alió, C., Simó, R., Jackson, A., Allen, A., and Degrandpre, M.D. (2008). A Lagrangian biogeochemical study of an eddy in the Northeast Atlantic. Progress in Oceanography 76, 366-398.

Johnson, R.A., and Wichern, D.W. (2007). Applied multivariate statistical analysis. Prentice-Hall. Kiørboe, T. (2001). Formation and fate of marine snow: small-scale processes with large-scale implications. Scientia Marina 65, 57-71.

Lambrechts, J., Humphrey, C., Mckinna, L., Gourge, O., Fabricius, K.E., Mehta, A.J., Lewis, S., and Wolanski, E. (2010). Importance of wave-induced bed liquefaction in the fine sediment budget of Cleveland Bay, Great Barrier Reef. Estuarine, Coastal and Shelf Science 89, 154-162.

Lønborg, C., Álvarez-Salgado, X.A., Duggan, S., and Carreira, C. (2018). Organic matter bioavailability in tropical coastal waters: The Great Barrier Reef. Limnology \& Oceanography 63, 1015-1035.

Lønborg, C., Doyle, J., Furnas, M., Menendez, P., Benthuysen, J.A., and Carreira, C. (2017). Seasonal organic matter dynamics in the Great Barrier Reef lagoon: Contribution of carbohydrates and proteins. Continental Shelf Research 138, 95-105.

Malmcrona-Friberg, K., Goodman, A., and Kjelleberg, S. (1990). Chemotactic responses of marine Vibrio sp. strain S14 (CCUG 15956) to low-molecular-weight substances under starvation and recovery conditions. Applied and Environmental Microbiology 56, 36993704.

Pinhassi, J., GóMez-Consarnau, L., Alonso-SáEz, L., Sala, M.M., Vidal, M., PedróS-Alió, C., and Gasol , J.M. (2006). Seasonal changes in bacterioplankton nutrient limitation and their effects on bacterial community composition in the NW Mediterranean Sea. Aquatic Microbial Ecology 44, 241-252.

Pope, S.B. (2000). Turbulent Flows. Cambridge University Press.

PeerJ reviewing PDF | (2020:04:47529:1:1:NEW 1 Jul 2020) 
562 Revelante, N., Williams, W.T., and Bunt, J.S. (1982). Temporal and spatial distribution of diatoms,

563

564

565

566

567

568

569

570

571

572

573

574

575

576

577

578

579

580

581

582

583

584

585

586

587

588

589

590

591

592

593

594 dinoflagellates and Trichodesmium in waters of the Great Barrier Reef. Journal of Experimental Marine Biology and Ecology 63, 22-45.

Seymour, J.R., Patten, N., Bourne, D.G., and Mitchell, J.G. (2005). Spatial dynamics of virus-like particles and heterotrophic bacteria within a shallow coral reef system. Marine Ecology Progress Series 288, 1-8.

Seymour, J.R., Seuront, L., Doubell, M., Waters, R.L., and Mitchell, J.G. (2006). Microscale patchiness of virioplankton. Journal of the Marine Biological Association of the United Kingdom 86, 551-561.

Silveira, C.B., and Rohwer, F.L. (2016). Piggyback-the-Winner in host-associated microbial communities. NPJ Biofilms Microbiomes 2, 16010.

Sokal, R.R., and Rohlf, F.J. (eds.). (1995). Biometry the principles and practice of statistics in biological research. New York: W. H. Freeman and Company.

Stocker, R. (2015). The $100 \mu \mathrm{m}$ length scale in the microbial ocean. Aquatic Microbial Ecology 76, 189-194.

Stocker, R., and Seymour, J.R. (2012). Ecology and Physics of Bacterial Chemotaxis in the Ocean. Microbiology and Molecular Biology Reviews 76, 792-812.

Stocker, R., Seymour, J.R., Samadani, A., Hunt, D.E., and Polz, M.F. (2008). Rapid chemotactic response enables marine bacteria to exploit ephemeral microscale nutrient patches. Proceedings of the National Academy of Sciences 105, 4209-4214.

Strickland, J.D.H., and Parsons, T.R. (1972). A practical handbook of seawater analysis. Bull Fish Res Board Can 167, 1-310.

Suttle, C.A. (2005). Viruses in the sea. Nature 437, 356-361.

Uthicke, S., Furnas, M., and Lønborg, C. (2014). Coral reefs on the edge? Carbon chemistry on inshore reefs of the Great Barrier Reef. PLOS ONE 9.

Weber, L., and Apprill, A. (2020). Diel, daily, and spatial variation of coral reef seawater microbial communities. PLoS One 15, e0229442.

Wiens, J.A. (1989). Spatial scaling in ecology. Functional Ecology 3, 385-397.

Wigington, C.H., Sonderegger, D., Brussaard, C.P.D., Buchan, A., Finke, J.F., Fuhrman, J.A., Lennon, J.T., Middelboe, M., Suttle, C.A., Stock, C., Wilson, W.H., Wommack, K.E., Wilhelm, S.W., and Weitz, J.S. (2016). Re-examination of the relationship between marine virus and microbial cell abundances. Nature Microbiology, 1-8. 


\section{Table $\mathbf{1}$ (on next page)}

Sampling sites information

Great Barrier Reef (Australia) location names, sites identification number, latitude, longitude, sampling date, time, and the in-situ salinity and temperature. Sites 1 to 5 were each sampled once for the spatial study, while site 6 was sampled over 4 days for the temporal study. 


\begin{tabular}{|c|c|c|c|c|c|c|c|}
\hline Location & Site & Latitude & Longitude & Date & Time & Salinity & $\begin{array}{l}\text { Temperature } \\
\left({ }^{\circ} \mathrm{C}\right)\end{array}$ \\
\hline Rudder Reef & 1 & -16.20139 & 145.76722 & $17 / 12 / 2014$ & $8: 00 \mathrm{AM}$ & 35.5 & 30.1 \\
\hline Irene Reef & 2 & -15.64772 & 145.68234 & $17 / 12 / 2014$ & 2:50 PM & n.d. & n.d. \\
\hline Osterlund Reef & 3 & -15.55405 & 145.45964 & $18 / 12 / 2014$ & 11:00 AM & 35.6 & 29.4 \\
\hline Coral Sea & 4 & -15.55972 & 145.97222 & $19 / 12 / 2014$ & 11:20 AM & 35.3 & 28.8 \\
\hline Flora Reef & 5 & -17.22020 & 146.25450 & $22 / 12 / 2014$ & $\begin{array}{l}\text { 11:00 AM } \\
\text { High Tide }\end{array}$ & 35.5 & 28.7 \\
\hline Bowling Green Bay & 6 & -19.27602 & 147.05744 & $12-15 / 01 / 2015$ & $\begin{array}{l}(2: 20 \mathrm{PM}- \\
5: 45 \mathrm{PM})\end{array}$ & $32-33$ & $31-32$ \\
\hline
\end{tabular}




\section{Table 2 (on next page)}

Spatial study data

Total and per site average ( \pm standard deviation, SD), minimum (Min) and maximum (Max) values for nitrate/nitrite $\left(\mathrm{NO}_{3}{ }^{-} / \mathrm{NO}_{2}{ }^{-}\right)$, phosphate $\left(\mathrm{HPO}_{4}{ }^{2-}\right)$, dissolved organic carbon (DOC), total dissolved nitrogen (TDN), chlorophyll a (chl a), bacterial and viral abundances, and virus to bacteria ratio (VBR) measured at the sites 1 to 5 included in the spatial study in the Great Barrier Reef (Australia); n.d. - not determined. 


\begin{tabular}{|c|c|c|c|c|c|c|c|c|c|}
\hline Site & Calculation & $\begin{array}{l}\mathrm{NO}_{3}^{-} / \mathrm{NO}_{2}^{-} \\
\left(\mu \mathrm{mol} \mathrm{l}^{-1}\right)\end{array}$ & 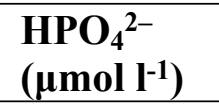 & $\begin{array}{l}\text { DOC } \\
\left(\mu \mathrm{mol} \mathrm{l}^{-1}\right)\end{array}$ & $\begin{array}{l}\text { TDN } \\
\left(\mu \mathrm{mol} \mathrm{l}^{-1}\right)\end{array}$ & $\begin{array}{l}\text { Chl a } \\
\left(\mu \mathrm{g} \mathrm{l^{-1 }}\right)\end{array}$ & $\begin{array}{l}\text { Bacteria } \\
\left(\times 10^{5} \mathrm{ml}^{-1}\right)\end{array}$ & $\begin{array}{l}\text { Viruses } \\
\left(\times 10^{5} \mathrm{ml}^{-1}\right) \\
\end{array}$ & VBR \\
\hline \multirow{3}{*}{1} & Average \pm SD & $0.07 \pm 0.02$ & $0.06 \pm 0.02$ & $90 \pm 9$ & $8.4 \pm 0.9$ & $0.44 \pm 0.21$ & $7.8 \pm 0.5$ & $51.9 \pm 3.4$ & $6.7 \pm 0.7$ \\
\hline & Min - Max & $0.05-0.16$ & $0.04-0.09$ & $75-106$ & $6.9-10.2$ & $0.11-0.88$ & $7.3-9.6$ & $45.6-60.6$ & $3.5-7.4$ \\
\hline & CV (\%) & 37 & 27 & 10 & 11 & 47 & 7 & 6 & 10 \\
\hline \multirow{3}{*}{2} & Average \pm SD & $0.06 \pm 0.01$ & & $83 \pm 11$ & $6.5 \pm 0.8$ & $0.50 \pm 0.21$ & $9.6 \pm 0.3$ & $58.2 \pm 8.8$ & $6.1 \pm 1.0$ \\
\hline & Min - Max & $0.05-0.08$ & n.d. & $72-112$ & $5.3-8.6$ & $0.14-0.79$ & $8.8-10.2$ & $35.6-72.8$ & $3.5-7.4$ \\
\hline & CV (\%) & 20 & & 13 & 12 & 43 & 4 & 15 & 16 \\
\hline \multirow{3}{*}{3} & Average \pm SD & $0.08 \pm 0.01$ & $0.05 \pm 0.01$ & $85 \pm 11$ & $6.8 \pm 1.6$ & $0.51 \pm 0.23$ & $12.5 \pm 1.9$ & $47.0 \pm 6.9$ & $3.8 \pm 0.6$ \\
\hline & Min - Max & $0.05-0.10$ & $0.04-0.07$ & $72-112$ & $2.1-10.1$ & $0.06-1.12$ & $11.2-20.5$ & $37.7-67.2$ & $2.8-4.7$ \\
\hline & CV $(\%)$ & 15 & 21 & 13 & 24 & 46 & 15 & 15 & 15 \\
\hline \multirow{3}{*}{4} & Average \pm SD & $0.06 \pm 0.01$ & $0.07 \pm 0.01$ & $89 \pm 8$ & $6.5 \pm 0.6$ & $0.34 \pm 0.18$ & $5.5 \pm 0.3$ & $18.9 \pm 1.1$ & $3.4 \pm 0.3$ \\
\hline & Min - Max & $0.05-0.11$ & $0.04-0.11$ & $77-104$ & $5.6-7.7$ & $0.04-0.69$ & $5.2-6.5$ & $17.4-21.4$ & $2.9-4.1$ \\
\hline & CV $(\%)$ & 21 & 20 & 9 & 9 & 54 & 5 & 6 & 9 \\
\hline \multirow{3}{*}{5} & Average \pm SD & $0.05 \pm 0.01$ & $0.04 \pm 0.01$ & $86 \pm 5$ & $8.1 \pm 1.1$ & $0.25 \pm 0.17$ & $10.1 \pm 0.6$ & $41.3 \pm 2.7$ & $4.1 \pm 0.3$ \\
\hline & Min - Max & $0.05-0.07$ & $0.04-0.08$ & $78-102$ & $6.1-10.4$ & $0.05-0.62$ & $9.4-12.5$ & $36.2-45.3$ & $3.2-4.7$ \\
\hline & CV $(\%)$ & 10 & 20 & 6 & 13 & 68 & 6 & 7 & 9 \\
\hline \multirow{2}{*}{$\begin{array}{l}\text { Tota } \\
\text { l }\end{array}$} & Average \pm SD & $0.06 \pm 0.02$ & $0.06 \pm 0.02$ & $86 \pm 9$ & $7.3 \pm 1.3$ & $0.41 \pm 0.22$ & $9.1 \pm 2.5$ & $\begin{array}{l}43.4 \pm \\
14.5\end{array}$ & $4.8 \pm 1.5$ \\
\hline & Min - Max & $0.05-0.16$ & $0.04-0.11$ & $72-112$ & $2.1-10.4$ & $0.04-1.12$ & $5.2-20.5$ & $17.4-72.8$ & $2.8-8.3$ \\
\hline
\end{tabular}




\section{Table 3 (on next page)}

Temporal study data

Total and per day average ( \pm standard deviation, SD), and minimum (Min) and maximum (Max) values for nitrate/nitrite $\left(\mathrm{NO}_{3}{ }^{-} / \mathrm{NO}_{2}{ }^{-}\right)$, phosphate $\left(\mathrm{HPO}_{4}{ }^{2-}\right)$, dissolved organic carbon (DOC), total dissolved nitrogen (TDN), chlorophyll a (chl a), bacterial and viral abundances, and virus to bacteria ratio (VBR) measured during the 4 days of the temporal study at Bowling Green Bay (site 6) in the Great Barrier Reef (Australia); n.d. - not determined. 


\begin{tabular}{|c|c|c|c|c|c|c|c|c|c|}
\hline Day & Calculation & $\begin{array}{l}\mathrm{NO}_{3}^{-} / \mathrm{NO}_{2}^{-} \\
\left(\mu \mathrm{mol} \mathrm{l}^{-1}\right)\end{array}$ & $\begin{array}{l}\mathrm{HPO}_{4}{ }^{2-} \\
\left(\mu \mathrm{mol} \mathrm{l^{-1 }}\right)\end{array}$ & 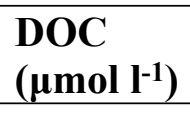 & 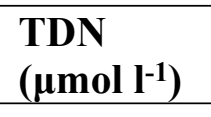 & $\begin{array}{l}\text { Chl a } \\
\left(\mu \mathrm{g} \mathrm{l}^{-1}\right)\end{array}$ & $\begin{array}{l}\text { Bacteria } \\
\left(\times 10^{5} \mathrm{ml}^{-1}\right)\end{array}$ & $\begin{array}{l}\begin{array}{l}\text { Viruses } \\
\left(\times 10^{5} \mathrm{ml}^{-1}\right)\end{array} \\
\end{array}$ & VBR \\
\hline \multirow{2}{*}{1} & Average \pm SD & $0.06 \pm 0.03$ & $0.08 \pm 0.01$ & $107 \pm 4$ & $8.9 \pm 0.8$ & $0.27 \pm 0.18$ & $20.3 \pm 0.9$ & $98.9 \pm 9.2$ & $4.9 \pm 0.5$ \\
\hline & CV $(\%)$ & 45 & 12 & 4 & 9 & 65 & 5 & 9 & 10 \\
\hline \multirow{2}{*}{2} & Average \pm SD & $0.08 \pm 0.0$ & $0.07 \pm 0.01$ & $101 \pm 4$ & & $0.24 \pm 0.15$ & $19.8 \pm 2.0$ & $121.1 \pm 15.7$ & $6.2 \pm 1.0$ \\
\hline & CV $(\%)$ & 19 & 13 & 4 & & 63 & 10 & 13 & 16 \\
\hline \multirow[b]{2}{*}{3} & Average \pm SD & $0.18 \pm 0.02$ & $0.09 \pm 0.01$ & $118 \pm 6$ & & $0.16 \pm 0.12$ & $17.9 \pm 3.3$ & $111.0 \pm 12.4$ & $6.4 \pm 1.3$ \\
\hline & Min - Max & $0.15-0.21$ & $0.07-0.11$ & $109-135$ & n.d. & $0.05-0.67$ & $13.0-24.1$ & $94.8-160.0$ & $4.0-8.2$ \\
\hline \multirow[t]{2}{*}{4} & Min - Max & $0.47-0.82$ & $0.07-0.16$ & $94-113$ & $10.2-12.7$ & $0.07-0.48$ & $12.1-16.4$ & $68.8-108.0$ & $5.0-7.3$ \\
\hline & CV (\%) & 15 & 26 & 4 & 6 & 52 & 6 & 12 & 12 \\
\hline \multirow{2}{*}{ Total } & Average \pm SD & $0.24 \pm 0.24$ & $0.09 \pm 0.02$ & $106 \pm 8$ & $10.1 \pm 1.4$ & $0.22 \pm 0.14$ & $18.1 \pm 3.1$ & $104.8 \pm 17.3$ & $5.9 \pm 1.1$ \\
\hline & Min - Max & $0.05-0.82$ & $0.05-0.16$ & $94-135$ & $7.2-12.7$ & $0.01-0.67$ & $12.1-25.3$ & $68.8-160.0$ & $4.0-8.4$ \\
\hline
\end{tabular}


Figure 1

Sampling locations

Map showing the sampled location for study sites along the Great Barrier Reef (Australia). Larger map is a representation of the square indicated in the smaller map of Australia.

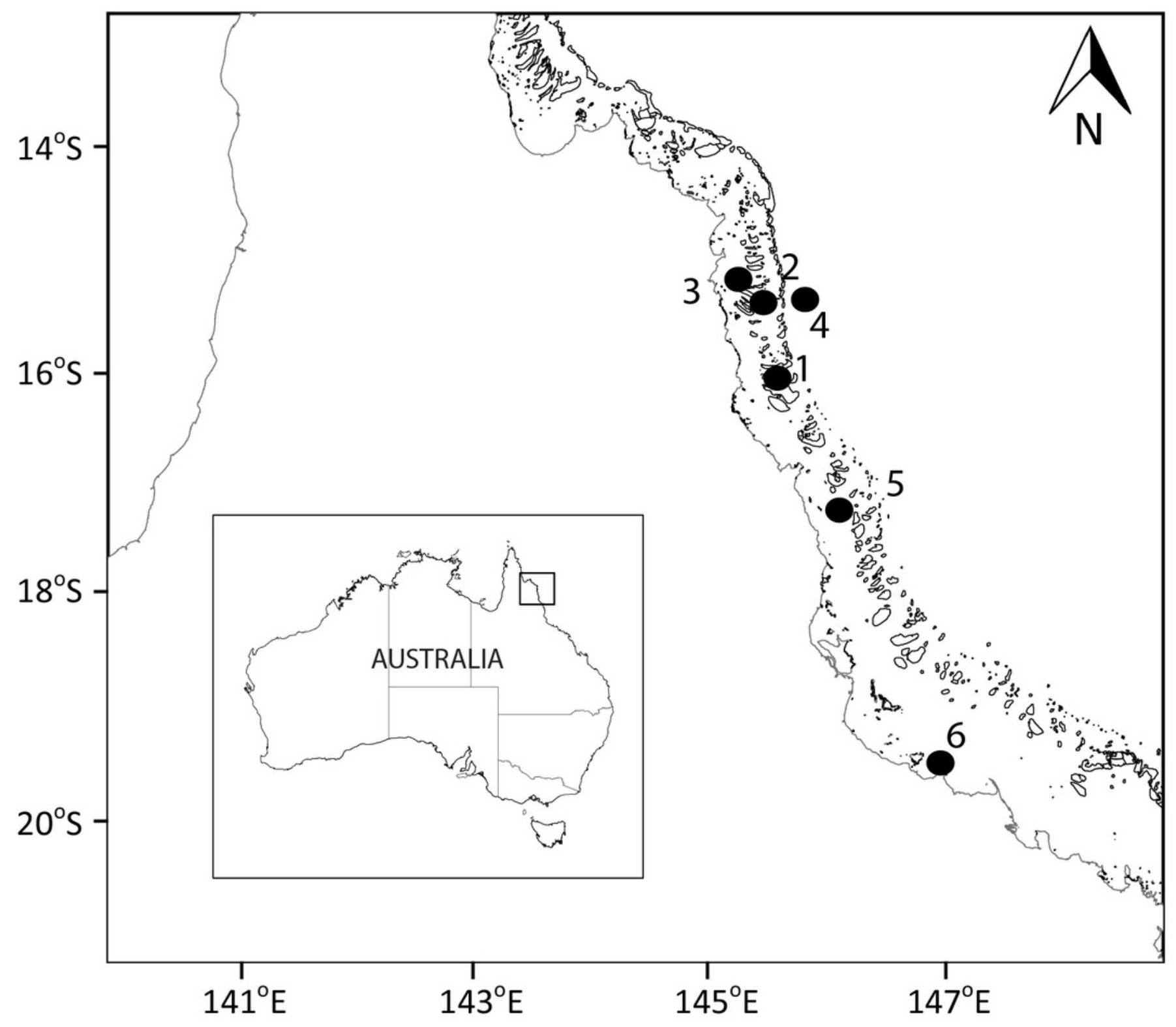


Figure 2

Sampling device

Two-dimensional device used for sampling consisting of 25 inlets $(5 \times 5)$ connected to a 25 $\mathrm{mL}$ syringe, each separated by $7 \mathrm{~cm}$ with a total sampling area of $784 \mathrm{~cm}^{2}$.

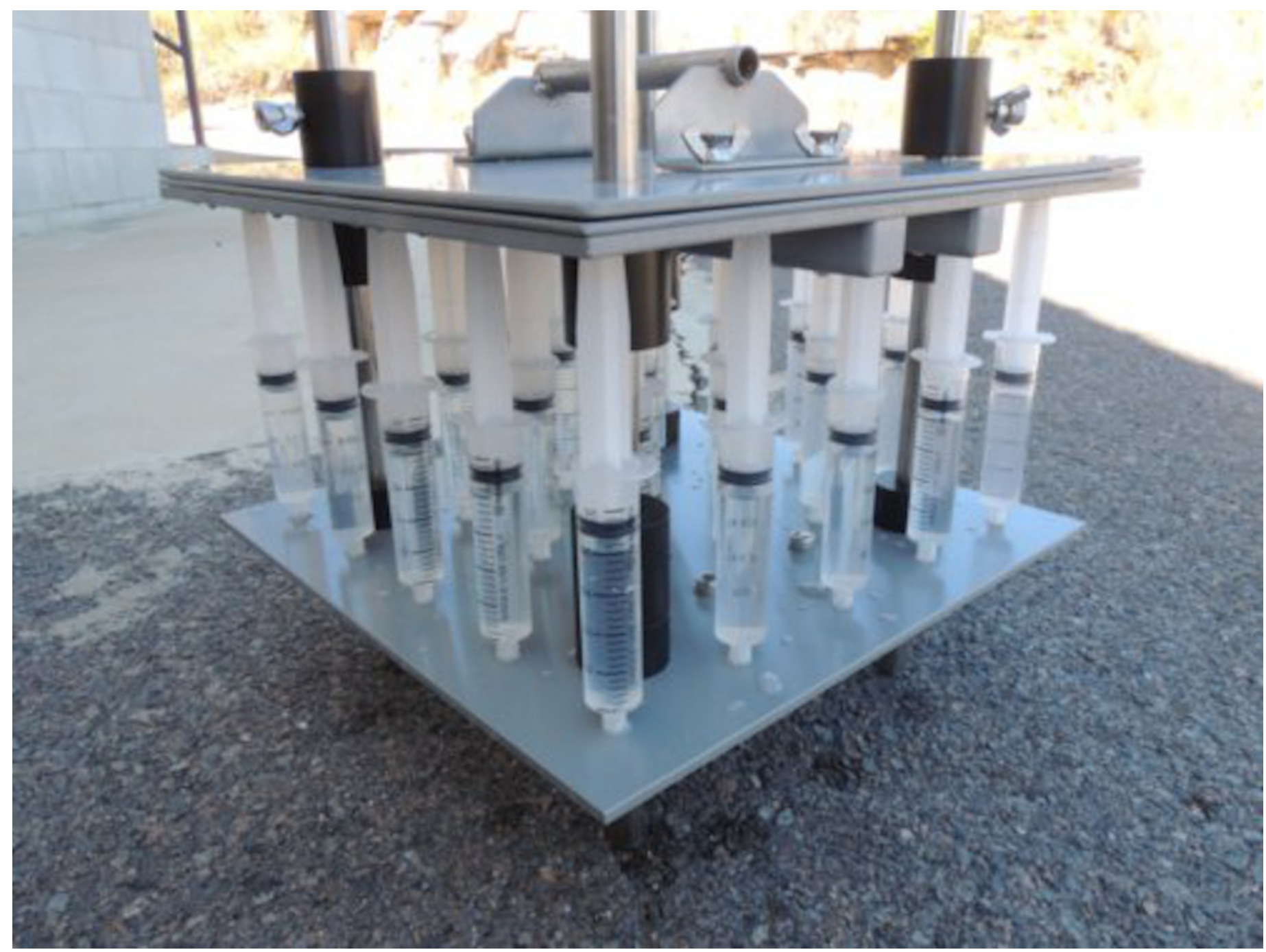




\section{Figure 3}

Spatial distribution of chemical parameters

Small-scale spatial distribution of nitrate/nitrite $\left(\mathrm{NO}_{3}^{-} / \mathrm{NO}_{2}^{-}\right)$, phosphate $\left(\mathrm{HPO}_{4}{ }^{2-}\right)$, dissolved organic carbon (DOC), total dissolved nitrogen (TDN; top to bottom) measured at the 5 sites (left to right) of the spatial study in the Great Barrier Reef (Australia). The grey scale represents the range of concentrations for each parameter, with white being the lowest concentration and black the highest. The axes represent the $28 \mathrm{~cm}$ spatial array used for sampling. 


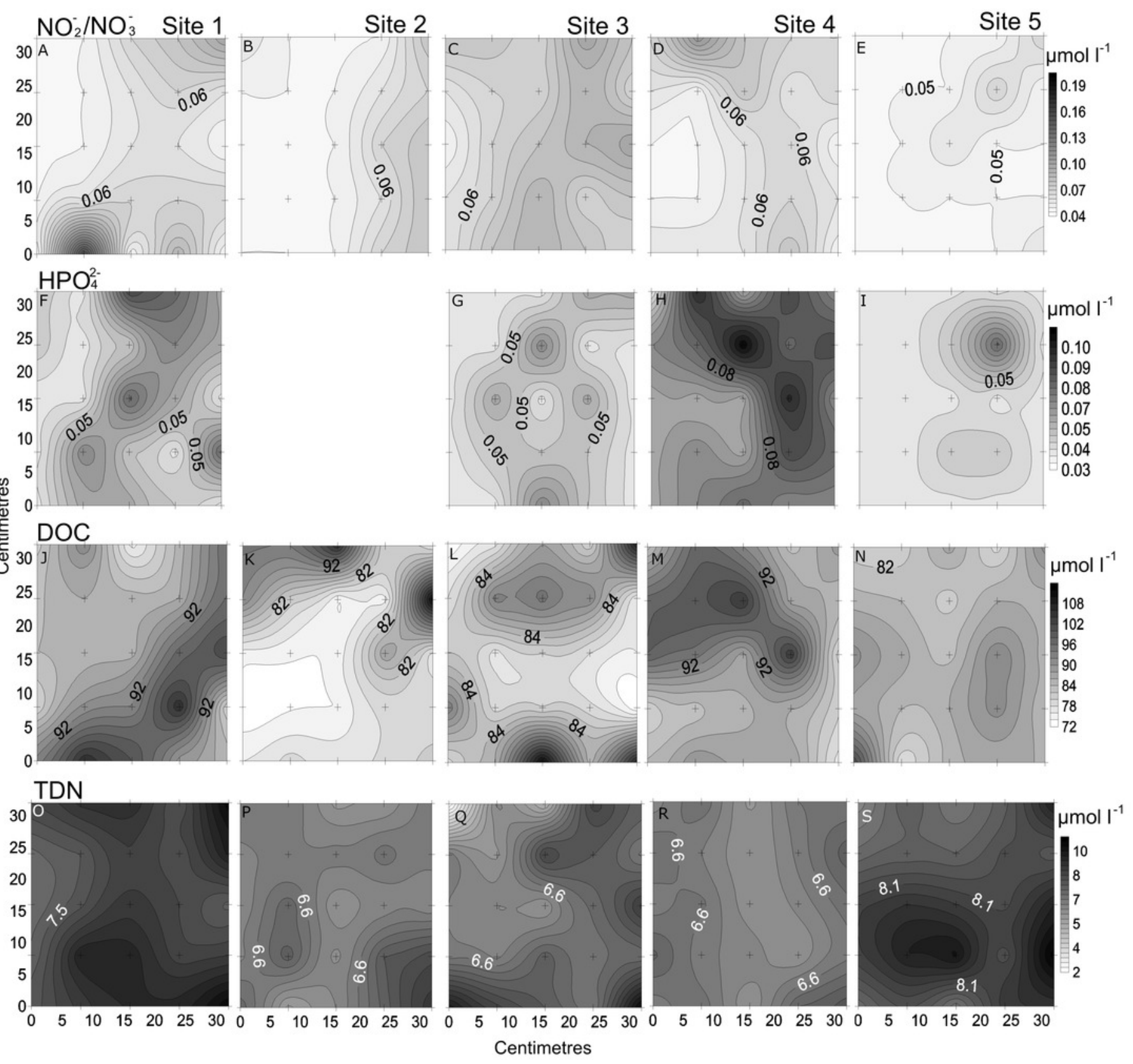




\section{Figure 4}

Temporal distribution of chemical parameters

Small-scale spatial distribution of nitrate/nitrite $\left(\mathrm{NO}_{3}^{-} / \mathrm{NO}_{2}^{-}\right)$, phosphate $\left(\mathrm{HPO}_{4}{ }^{2-}\right)$, dissolved organic carbon (DOC), total dissolved nitrogen (TDN; top to bottom) measured during the 4 days (left to right) of the temporal study in the Great Barrier Reef (Australia). The grey scale represents the range of concentrations for each parameter, with white being the lowest concentration and black the highest. The axes represent the $28 \mathrm{~cm}$ spatial array used for sampling. 


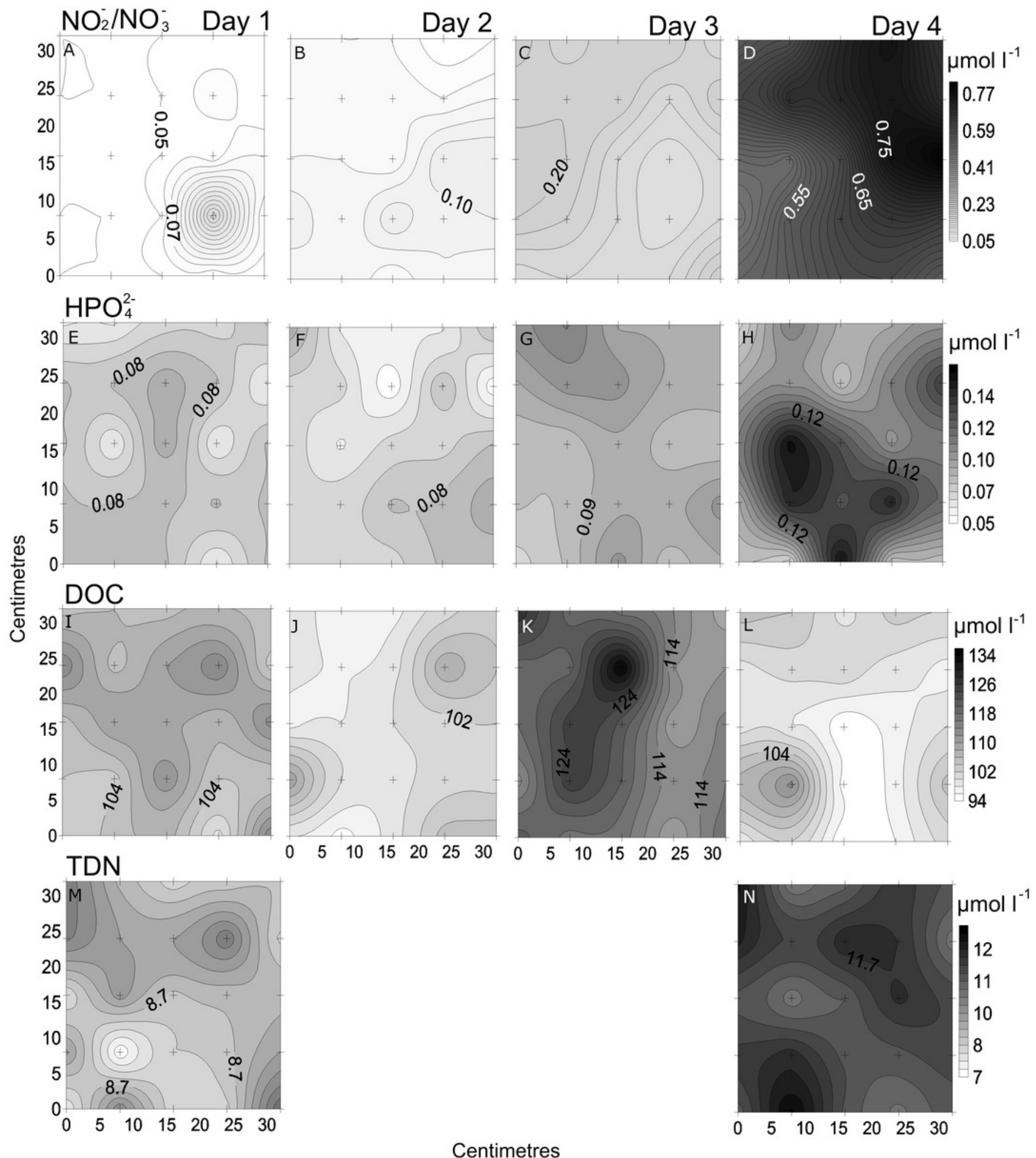




\section{Figure 5}

Spatial distribution of biological parameters

Small-scale spatial distribution of chlorophyll a (chl a), bacteria, viruses, and virus-to bacteria ratio (VBR; top to bottom) measured at the 5 sites (left to right) of the spatial study in the Great Barrier Reef (Australia). The grey scale represents the range of concentrations for each parameter, with white being the lowest concentration and black the highest. The axes represent the $28 \mathrm{~cm}$ spatial array used for sampling. 


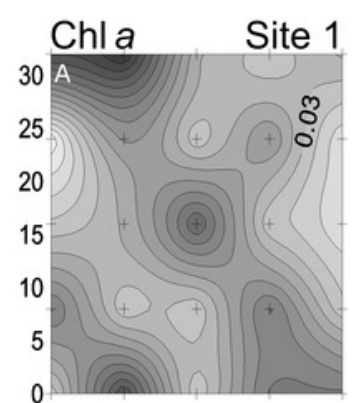

Site 2

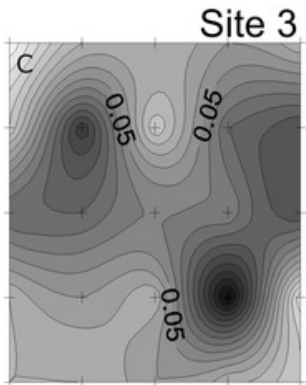

Site 4
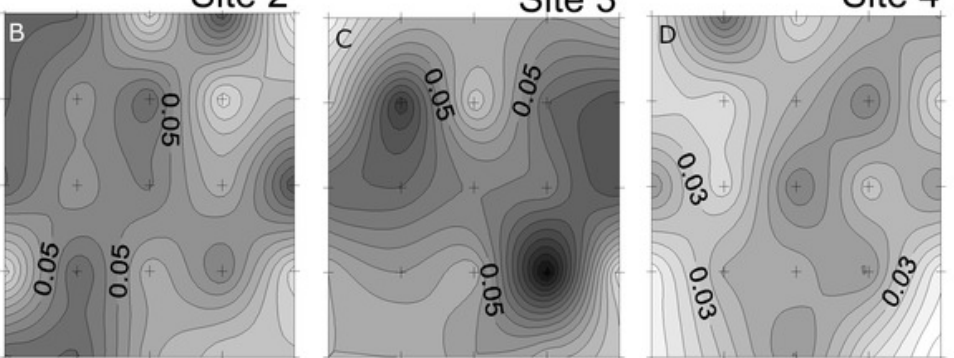

Site 5
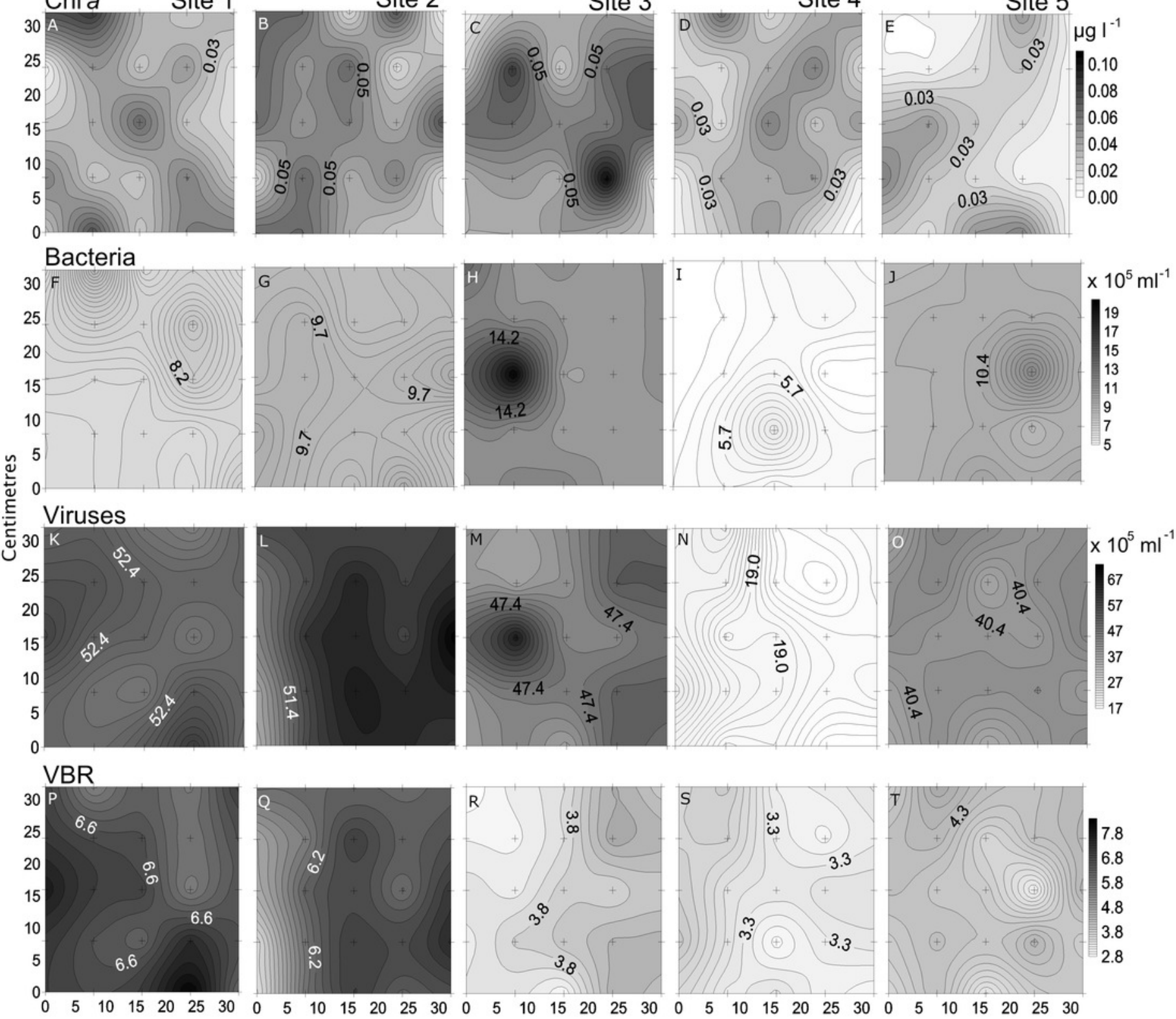

Centimetres 


\section{Figure 6}

Temporal distribution of biological parameters

Small-scale spatial distribution of chlorophyll a (chl a), bacteria, viruses, and the virus to bacteria ratio (VBR; top to bottom) measured during the 4 days (left to right) of the temporal study in the Great Barrier Reef (Australia). The grey scale represents the range of concentrations for each parameter, with white being the lowest concentration and black the highest. The axes represent the $28 \mathrm{~cm}$ spatial array used for sampling. 


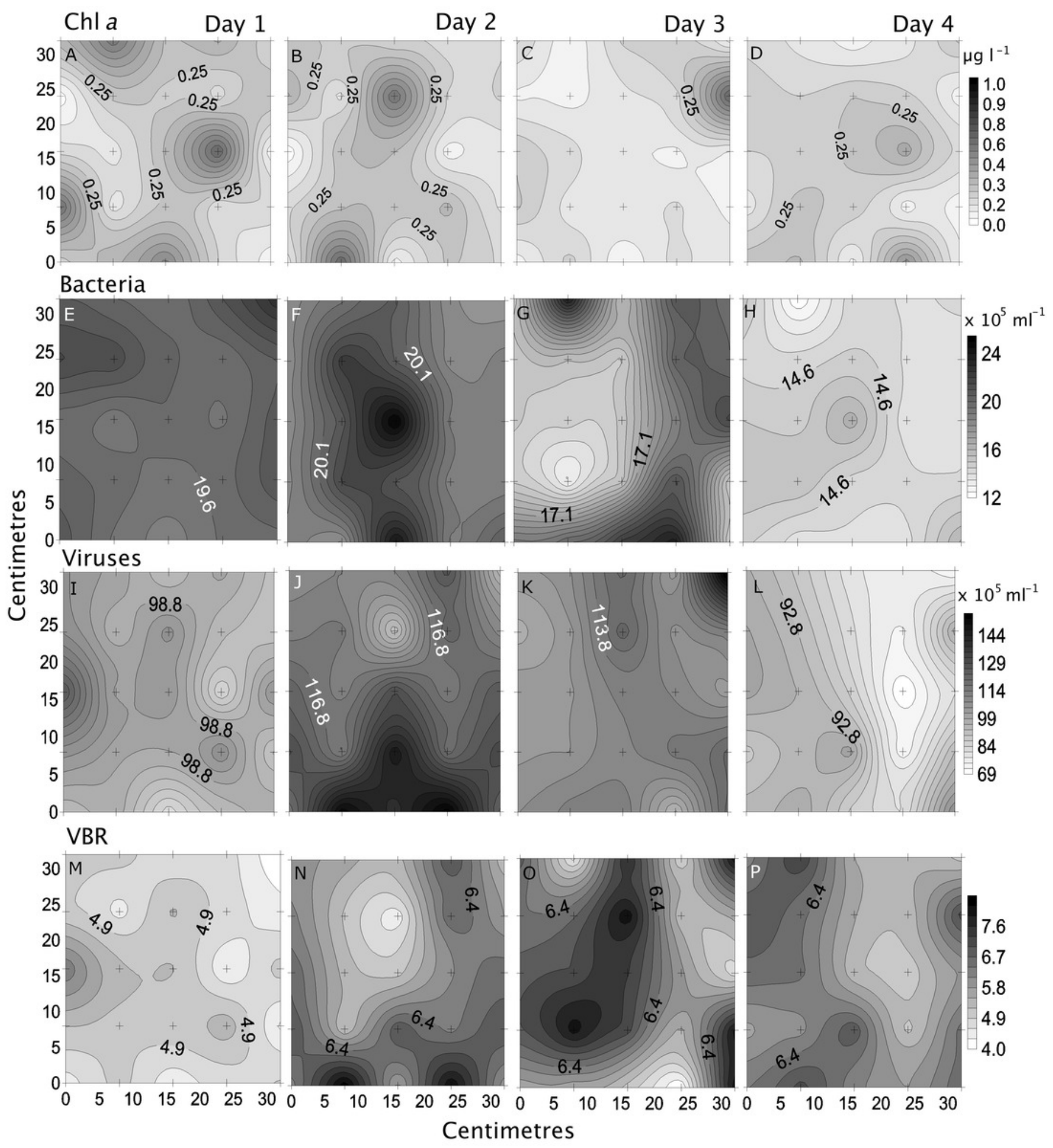




\section{Figure 7}

Spatial distribution of biological parameters at large-scale

Boxplots of each chemical (A-nitrate/nitrite - $\mathrm{NO}_{3}{ }^{-} / \mathrm{NO}_{2}{ }^{-}, \mathrm{B}$-phosphate - $\mathrm{HPO}_{4}{ }^{2-}, \mathrm{C}$-dissolved organic carbon - DOC, and D-total dissolved nitrogen - TDN), and biological parameter (Echlorophyll a - chl a, F-bacteria, and G-viruses) for the sampled sites (1, 2, 3, 4, and 5) in the Great Barrier Reef (Australia). Error bars represent the $10^{\text {th }}$ and $90^{\text {th }}$ percentiles, with $50 \%$ of the data inside the box. The solid line inside the box represents the median. Each site had a sample size of $n=25$. Boxplots showing the same letter are not significantly different $(P<$ 0.05). 


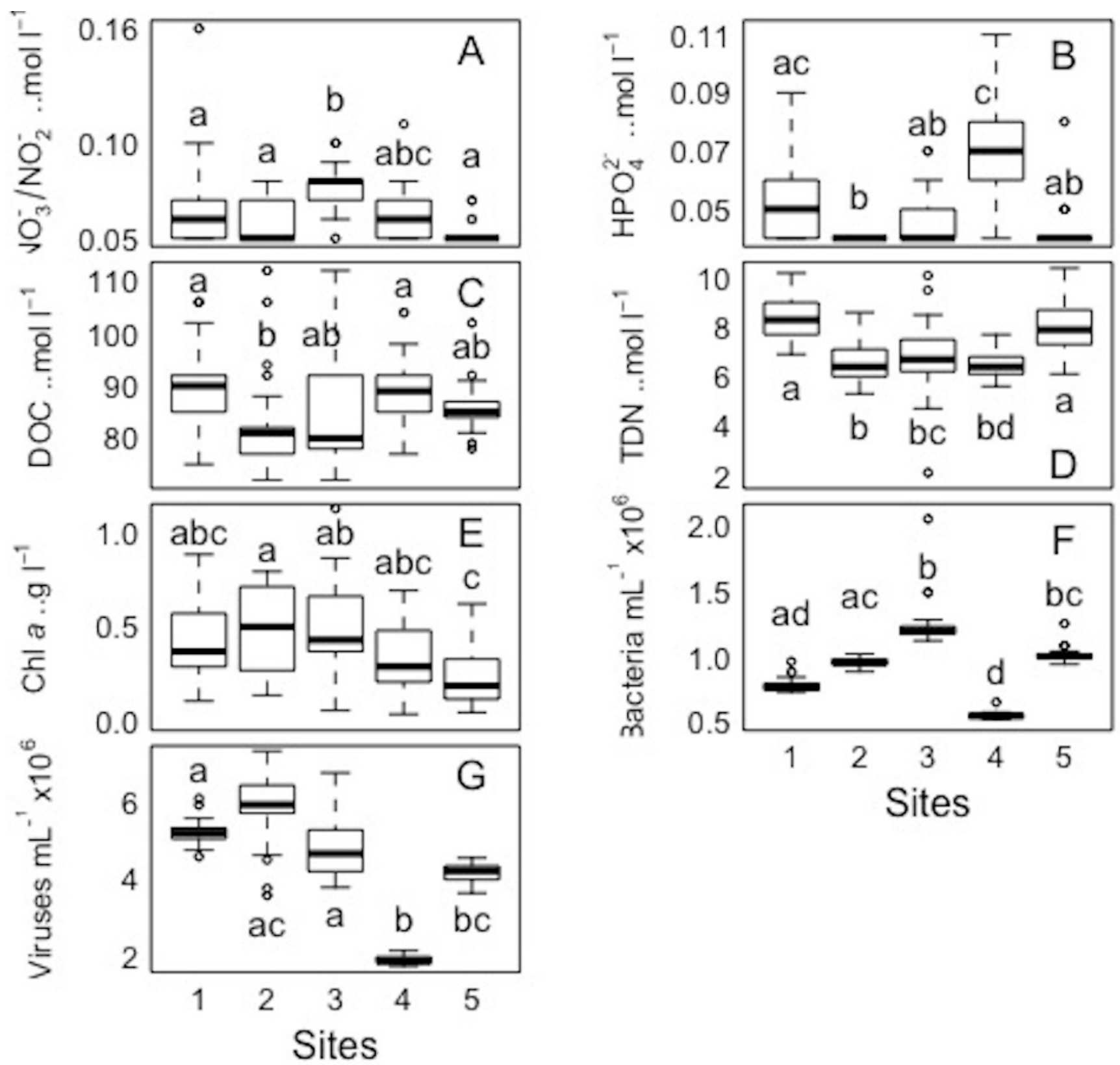




\section{Figure 8}

Temporal distribution of biological parameters at large-scale

Boxplots of each chemical (A-nitrate/nitrite - $\mathrm{NO}_{3}^{-} / \mathrm{NO}_{2}{ }^{-}$, B-phosphate - $\mathrm{HPO}_{4}{ }^{2-}$, and C-dissolved organic carbon - DOC), and biological parameter (D-chlorophyll a - chl a, E-bacteria, and Fviruses) for the sampled days (1, 2, 3, and 4) in the Great Barrier Reef (Australia) at Bowling Green Bay (site 6). Error bars represent the $10^{\text {th }}$ and $90^{\text {th }}$ percentiles, with $50 \%$ of the data inside the box. The solid line inside the box represents the median. Each day had a sample size of $n=25$. Boxplots showing the same letter are not significantly different $(P<0.05)$. 


Figure 9

Linear regression

Between the abundances of bacteria and viruses from all the sites $(1,2,3,4$, and 5$)$ and days $(1,2,3$, and 4$)$ measured in the Great Barrier Reef (Australia) $\left(n=325 ; R^{2}=0.75 ; p<\right.$ $0.0001 ;$ Vir $=5.4 \pm 0.3$ Bact).



